\title{
A Study of the antecedents of purchase decision of luxury brands
}

\author{
Dr. R. Srinivasan, Dr. R. K. Srivastava and Sandeep Bhanot
}

\begin{abstract}
This is one of the first investigations of consumer motivations for purchasing luxury brands in India, a country with an emerging middle class. It identifies four dimensions of luxury benefits for segmenting markets. These include the financial, functional, personal, and social benefits of luxury value. Using data collected from 329 respondents in Mumbai the study identifies nine luxury factors for purchase behaviour. These are used for classifying respondents into three behavioural segments using cluster analysis. The first segment appears to buy luxury goods primarily for their snob appeal, the second segment for their prestige appeal, and the third for their value appeal. The results show that while many consumers may buy the same luxury goods, their motivations for doing so differ. The findings should help marketers tailor their messages to specific luxury-seeking segments.
\end{abstract}

Keywords: Consumer behaviour, luxury, market segmentation

\section{Introduction}

People have sought luxury in various forms since the beginning of civilization. Luxury consumption played an important role in ancient empires and remains important modern societies. In traditional civilizations characterized by clearly delimited social classes, luxury was limited to aristocratic classes. As such, luxury has been defined as goods that only the wealthier classes of society can afford to buy.

However, increasing social mobility and accompanying increases in purchasing power among more segments of society has led to what Wong and Ahuvia (1998) described as the 'democratization' of luxury. Democratization has made a wide variety of luxury goods accessible to up-and-coming market segments. Such accessible or mass luxury targets the middle class.

In recent decades, most upward mobility and growth in luxury consumption has occurred outside developed economies in Western Europe per the research from A.T. Kearney (Luxury Daily, 2013). China is the leading market for luxury brands along with North America, Japan and the developing BRIC economies of Brazil, China, India, and Russia. The emerging middle classes of these four countries account for much of the growth in the global luxury market. In addition to the BRIC countries, other emerging economies such as Chile, Uruguay, and Georgia are proving to be valuable global retail markets for luxury brands where they should currently be focusing their attention, according to one of the panels at the Luxury Briefing Wealth Summit 2011. Since U.S. consumers are yet to start spending again, the Boston Consulting Group recommends that luxury brands should concentrate their efforts on emerging markets, such as the BRIC countries, (Luxury Daily, 2013).

China and India share a similar history with respect to the availability of luxury goods. Luxury goods that were commonplace suddenly vanished due to political factors such as closed borders, government disapproval of luxuries and price inaccessibility. Now that both countries have open borders and burgeoning middle classes, many Chinese and Indians are able to afford luxury products (Danziger, 2005; Thomas, 2007). Chadha and Husband(2006) discuss such political and historical affects on luxury consumption by explaining that consumers are motivated to buy luxury products with great enthusiasm as a means of self-expression and rebelling against the subjugation of the past.

The Indian luxury market is expected to grow by $250 \%$ over the next 5 years fuelled by the dynamic lifestyles of traditionally wealthy people alongside the nouveau riche. According to the 'India Luxury Trends (2011-12) report' by Technopak, over the past decade, the Indian economy grew by USD \$ 975 million and is expected to add twice that amount over the next decade. By 2020, India's economy will rival developed countries like the United Kingdom, France or Italy.

The number of Indian millionaires has grown over the past decade (and is expected to grow throughout the next) fuelled by a robust economy, resurgent stock market and keen entrepreneurial drive. Recently, the number of Indian millionaires doubled from one year to the next. India ranks 12th amongst the countries having the maximum number of high net worth (HNI) individuals and is second only to Hong Kong in term of growth rates of this consumer segment.

The growth in luxury consumption is not limited to India's millionaires. The 2011-12 Technopak study reported that there are more than two million Indian households with incomes exceeding US $\$ 100,000$. This number is expected to grow by an annual rate of $13 \%$ over the next several years. Another fast-growing segment of Indian households earn between US \$50,000 and \$100,000. Together, these two middle-class are expected to drive the $20 \%$ annual growth in the luxury sector which is expected to reach US $\$ 6.8$ Billion by 
2015 , more than double its current value of US $\$ 3$ billion. Figure 1 shows that Luxury assets currently comprise the largest share of the luxury market at $65 \%$, followed by services at $22 \%$ and products at $13 \%$.

Place Fig. I here

Given its enormous growth potential in the near future, it makes sense to study India's emerging luxury market. Beyond segmenting the Indian market by income (millionaires versus the simply rich) it is important that marketers understand other dimensions along which the Indian luxury goods can be segmented and targeted. That is the purpose of this study. It begins with a literature review focusing on how luxury has been and continues to be redefined, the ways in which luxury consumption behaviour and its antecedents have been studied, as well as schemas that have been used to segment luxury markets. This is followed by an empirical behavioural segmentation study based on a survey of 329 Indian consumers. It concludes with a discussion of managerial implications, limitations, and directions for future research.

\section{Literature Review}

\section{Defining Luxury}

Luxury is an abstract concept that means different things to different people across different cultures. Vigneron and Johnson (1999) suggested the definition of luxury as highest level of prestigious brands encompassing several physical and psychological values. Dubois and Laurent (1994) and Dubois et al. (2001) found that consumers' attitudes towards the concept of luxury vary considerably. Luxury products fulfil not only functional but also psychological needs (Dubois et al., 2001). Since the concept is subjective, it has been defined differently by different people. Its meaning is determined by personal and interpersonal motives and is therefore primarily built on consumer perception (Vigneron and Johnson, 2004).

As luxury goods have been sought by a wider swath of society through democratization (Wong and Ahuvia 1998), defining luxury has become more complex. (Shukla. 2010). Dubois (2004) defines 'luxury' as a specific (i.e. higher-priced) tier of offer in almost any product or service category. This is but one of many definitions of luxury. Some researchers have tried to capture the essence of luxury by focusing on price-quality relationships whereby higher prices signal luxury. Horiuchi (1984), Dubois \& Laurent (1994), Pantzalis (1995), Dubois \& Paternault ( 1997), Wong \& Ahuvia (1998) have written about the high price of luxury brands as an important attribute. Others have framed luxury in terms of uniqueness. From an experiential standpoint, Kapferer (2005) defines luxury goods as those that provide extra pleasure by flattering all senses at once. Several other researchers focus on exclusivity dimension and argue that luxury evokes a sense of belonging to a certain elite group. Pantzalis (1995) and Dubois \& Paternault (1997) have emphasised on exclusivity and uniqueness of luxury brands. Wikipedia (2013) describes how manufactured products attain luxury status through superior design, quality, durability and performance. Aaker, 1991; Quelch, 1987; O'Cass and Frost, 2002; Vigneron and Johnson, 2004 and Horiuchi (1984), Dubois and Laurent (1994), Dubois and Paternault (1997) have emphasised on the high quality of luxury brands. It seems as if every category of goods available includes a luxury tier of products which are marked by better quality, aesthetics, durability and performance.

Han, Nunes, and X. Drèze (2011) studied the role that luxury brands play in signalling status. Their research found that some people buy luxury goods and use them as status symbols to show off their purchasing power. The products themselves may not necessarily offer better quality or performance or looks. Rather, they buy them because others recognize them as symbols of wealth and success, Such conspicuous consumption is commonly exhibited through the purchase of luxury vehicles, watches, jewellery, designer clothing, yachts, as well as large residences and mansions. Braun and Wicklund, 1989; Hong and Zinkhan, 1995; Bagwell and Bernheim, 1996; and Corneo and Jeanne, 1997 have said that conspicuous consumption is an important attribute of luxury brands.

\section{Dimensionalising Luxury:}

Wiedmann et al. (2009) developed a luxury value model useful for studying the relationship between value perception and luxury consumption. Their model includes four luxury value dimensions: financial value, functional value, individual value and social value. Financial value concerns the amount of money invested in luxury consumption. Functional value relates to the usefulness of the luxury product. Individual value captures the personal expressiveness and identification with luxury brand. The fourth dimension social value is used to explain how purchasing luxury goods affect ones standing with respect to social groups. This last dimension encompasses the snob and prestige appeals of conspicuous consumption of luxury goods.

Different authors have addressed different combinations of these luxury value dimensions.

(a) Several authors have studied the financial value people derive from buying products they believe others cannot afford. Horiuchi (1984), Dubois \& Laurent (1994), Pantzalis(1995), Dubois \& Paternault ( 1997), Wong \& Ahuvia (1998) have written about the high price of luxury brands as an important attribute. (b) Others have 
studied luxury consumption from the perspective of the functional value luxury goods provide. Simply stated, some people buy luxury goods because they believe they offer superior quality and perform better, that they are more user friendly, or more unique than their non-luxury-brand competitors are. Some researchers have shown that some consumers buy luxury brands that they perceive as offering better quality and performance. Reasons consumers buy luxury brands is for the superior quality reflected in the brand name. Luxury brands are supposed to offer greater product quality and performance than non-luxury brands (Aaker, 1991; Quelch, 1987; O'Cass and Frost, 2002; Vigneron and Johnson, 2004). Others have shown that perceived usability value drives purchases of luxury goods. For example, Horiuchi (1984), Dubois and Laurent (1994), Dubois and Paternault (1997) have said that the product should have the best quality, should have good craftsmanship, should be preferably hand made and not mass produced. Still others have focused on the uniqueness value of luxury brands. For some consumers, the rarer or more unique a brand is, the more value it symbolizes, (Sun, 2011). Pantzalis (1995) and Dubois \& Paternault (1997) have emphasised on exclusivity and uniqueness of luxury brands. Veblen (1899) and Mason (1981) have written about conspicuous consumption of luxury brands. Leibenstein (1950) and Dubois \& Laurent (1994) have written about the snob effect of luxury brands. Luxury consumers seek brands that are available in more selective or exclusive retail outlets.(c) Several researchers have studied the social value of luxury consumption. Vigneron \& Johnson (1999), Wiedmann et al (2009), Han et al (2010) have studied the social orientation of luxury brands. Such social value has two sub-dimensions: snob value and prestige value. People seeking snob value derive value from buying scarce luxury goods that others cannot access. Prestige seeking consumers seek to conform to aspirational groups that consume such luxury goods to demonstrate that they belong to this group. Leibenstein (1950) and Mason $(1981,1995)$ have focused on snob effect and bandwagon effect. Braun and Wicklund, 1989; Hong and Zinkhan, 1995; Bagwell and Bernheim, 1996; and Corneo and Jeanne, 1997 have said that conspicuous consumption still plays a significant part in shaping preferences for many products which are purchased or consumed in public contexts. Bourne (1957) and Mason (1981 and 1992) have focused on the influence of reference groups on the consumption of prestige brands and found that the conspicuousness of a product was positively related to its susceptibility to reference group influence. (d) Individual value: This dimension represents the aspect of consumer's personal point of reference towards luxury consumption as well as addressing personal value (Danziger, 2005). Lipovetsky \& Roux (2003) and Geerts \& Veg-Sala (2011) have studied the personal oriented consumption of individuals and called it as emotional luxury. Social value can be associated with Self-identity, materialistic and hedonism values

Self-identity value: Self-concept can be defined as a "totality of an individual's thought and feelings having reference to him as an object" (Rozenberg, 1979). It is an individual's opinion of one's own ability, limitation, appearance and characteristics, including one's own personality (Graeff, 1996). Consumers want to know whether the image of the luxury matches with their accomplishments and success. Consumers may use luxury items to integrate symbolic meaning into their own identity (Vigneron and Johnson, 2004). Belk et al (1982), Kohli \& Thakor (1997), Bell et al (1991) have studied the ‘self-identity' value of luxury brands.

Materialistic value: Richins (1994) divides materialism into three parts: centrality, happiness and success. Centrality indicates that luxury possessions play a central role in the lives of materialists. Happiness is the belief that owning the right possessions leads to well-being and materialists believe that success can be judged by the things people own. Chaudhury \& Majumdar (2006) have emphasised on the materialistic value of luxury brands. He said that consumers are motivated to buy luxury brands because of their materialistic value.

Hedonic value: Several definitions of luxury have been given highlighting characteristics such as comfort, beauty (Dubois and Czellar, 2002) and pleasure (Kapferer, 1997). This shows that consumers may be attracted to luxury products because of a positive emotional experience. Emotional responses to luxury have been identified in research on the semiotics of luxury. These include aesthetic beauty, enjoyment and sensory pleasure as per Wiedmann et al., 2009.

Dhar \& Wertenbroch (2000) and Tynan et al (2008) have written about the hedonic value of luxury brands.

In emerging economies like India and China, we have a rapidly rising class of new-rich people who want to purchase luxury brands. They want to belong to the so-called high status group and show off their newly acquired wealth. They want to purchase luxury brands, which express their individuality, are unique and put them in a different league as compared to the middle classes. All the above dimensions of luxury value, namely financial value, functional value, social value and individual value influence their purchase of luxury brands.

De Barnier et al (2006) analyzed consumer perceptions of luxury in three countries: France, Russia and the United Kingdom. Their findings revealed four luxury dimensions common to respondents in all three countries. These were aesthetics, premium quality, product personal history, and expensiveness. Their findings 
suggest that respondents in all three countries are motivated to consume luxury goods for self-pleasure. Their study also suggests cross-cultural differences. For example, they show that the French were motivated by aspiration and the conspicuousness of the product, the British were motivated by functionality and luxury atmospherics, while the Russians were primarily motivated by functionality.

\section{Luxury Segmentation}

Another stream of the luxury consumption literature focuses on segmenting the luxury market by consumer motivations. For example, Teimourpour et al (2012) identified four segments of luxury seekers in Iran: materialists, social status consumers, rational luxury consumers, and non-luxury consumers. Using definition of luxury, including individual, functional, and social components, the authors identified four different types of luxury seeking consumers. The authors began by factor analyzing a multi-item scale containing individual, functional, and social components, the authors extracted eight factors. They then clustered consumers into segments based upon differences in the perceptions of luxury value. In a similar study, Shukla (2013) defined segments of luxury consumers with his so-called 4P classification including the following:

Patricians - super-rich consumers paying a premium for inconspicuously branded products. Parvenus - the nouveau riche consumers who show off by purchasing conspicuously branded products

Poseurs - non-rich consumers buying fake goods to show off pretending they belong to the luxury class. Proletarians - non rich consumers who cannot afford luxury goods and don't use brands to show off. Such a segmentation schema can be used to study the purchase behaviour of luxury customers especially in emerging BRIC economies where the number of high net worth individuals has been increasing over the last few years.

\section{Gap analysis and identification of variables}

There have many studies done on motivations for luxury purchase behaviour and dimensions for luxury value abroad but not much work has been done in India in this regard. Hence, this paper tries to find the motivations leading to the purchase behaviour of luxury brands and to understand the different luxury value perceptions among consumers in Mumbai. The study is also needed to find consumer segments by using the functional, financial, individual and social dimensions of luxury value. Value for money has not been studied as a dependent variable, which will depend on financial, functional, individual and social dimensions of luxury value. This is an area, which provides further scope for research.

Here we try to understand the important luxury value dimensions, which influence purchase behaviour. So purchase behaviour is the dependent variable and the different dimensions of luxury value (like financial value, functional value, social value and individual value) are the independent variables.

People buy luxury brands so that they can belong to the 'high society' group (HNI) and to show that they have been successful in their lives. They derive hedonic and materialistic pleasure on purchase of luxury brands and show that they buy brands, which set them apart from others. Hence, we are trying to study how the luxury dimensions like financial value, functional value, social value and individual value influence the purchase behaviour of luxury brands.

\section{Developing the theoretical construct}

There are four main key dimensions of luxury value perception, which influence purchase behaviour of luxury brands. These are financial value, functional value, social value and individual value.

The first dimension is financial dimension. It is related to monetary aspects of luxury consumption and it addresses the actual price of these products.

The second factor is functional dimension. It focuses on the core benefits and basic utilities of the product. This factor explains the perceived uniqueness and the perceived quality dimensions.

The third dimension is individual dimension, which shows the consumers' personal point of reference towards luxury consumption.

The last dimension is social dimension. It reflects the perceived value of consumers towards the luxury products within a certain social group, which might have a strong impact on the evaluation and inclination to consume luxury brands. The perceived conspicuousness, snob value and prestige value fits into the last dimension.

Considering these four main luxury dimensions into account, we have proposed the theoretical model shown in Fig. 2 (shown in annexure).

Place Fig. II here 


\section{Formulation of Hypotheses}

We have used the model developed by Wiedmann et al (2009) for explaining the various luxury value dimensions and added additional dimension to the model tested in emerging markets. There are four main key dimensions of luxury value perception, which influence purchase behaviour of luxury brands. These are financial value, functional value, social value and individual value.

The first dimension is financial dimension. It is related to monetary aspects of luxury consumption and it addresses the actual price of these products. The second factor is functional dimension. It focuses on the core benefits and basic utilities of the product. This factor explains the perceived uniqueness and the perceived quality dimensions. The third dimension is individual dimension, which shows the consumers' personal point of reference towards luxury consumption. The last dimension is social dimension. It reflects the perceived value of consumers towards the luxury products within a certain social group, which might have a strong impact on the evaluation and inclination to consume luxury brands. The perceived conspicuousness, snob value and prestige value fits into the last dimension. Based on the above model, we have formulated the following hypotheses:

(i) Financial value is related to monetary aspects of luxury consumption and it addresses the actual price of these products. We want to understand whether financial value significantly influences the purchase behaviour of luxury brands.

Ho: Financial value does not significantly influence the purchase behaviour of luxury brands

H1: Financial value significantly influences the purchase behaviour of luxury brands

The study by Wiedmann et al (2009) has shown that financial value is an important dimension of luxury value. We want to test whether this is applicable in our study.

(ii) Uniqueness value: Exclusivity and uniqueness is one of the important characteristics of a luxury brand. We want to understand whether uniqueness value significantly influences the purchase behaviour of luxury brands.

Ho: Uniqueness value does not significantly influence the purchase behaviour of luxury brands

H1: Uniqueness value significantly influences the purchase behaviour of luxury brands

The study by Wiedmann et al (2009) has shown that uniqueness value is an important dimension of luxury value. We want to test whether this is applicable in our study.

(iii) Quality value: Consumers may associate luxury products with superior brand quality so that they perceive more value from them. We want to understand whether quality value significantly influences the purchase behaviour of luxury brands.

Ho: Quality value does not significantly influence the purchase behaviour of luxury brands

H1: Quality value significantly influences the purchase behaviour of luxury brands

The study by Wiedmann et al (2009) has shown that quality value is an important dimension of luxury value. We want to test whether this is applicable in our study.

(iv) Usability value: The core benefit of a product or service can be seen in its usability for satisfying consumer needs. We want to understand whether usability value significantly influences the purchase behaviour of luxury brands.

Ho: Usability value does not significantly influence the purchase behaviour of luxury brands

H1: Usability value significantly influences the purchase behaviour of luxury brands

The study by Wiedmann et al (2009) has shown that usability value is an important dimension of luxury value. We want to test whether this is applicable in our study.

(v) Snob value: People want to purchase luxury products because they are scarce and not easily available. We want to understand whether snob value significantly influences the purchase behaviour of luxury brands.

Ho: Snob value does not significantly influence the purchase behaviour of luxury brands

$\mathrm{H} 1$ : Snob value significantly influences the purchase behaviour of luxury brands

Snob value has not been considered in the previous studies as observed in the gap analysis. Hence we want to test whether this is applicable in our study.

(vi) Prestige value: This is the pursuit of status through consumption of luxury brands. People want to conform to those groups who possess such products and want to be different from those groups who do not possess such products. We want to understand whether prestige value significantly influences the purchase behaviour of luxury brands.

Ho: Prestige value does not significantly influence the purchase behaviour of luxury brands

H1: Prestige value significantly influences the purchase behaviour of luxury brands

The study by Wiedmann et al (2009) has shown that prestige value is an important dimension of luxury value. We want to test whether this is applicable in our study.

(vii) Self-identity value: Self-concept can be defined as a "totality of an individual's thought and feelings having reference to him as an object" (Rozenberg, 1979). It is an individual's opinion of his /her own ability, limitation, appearance and characteristics, including one's own personality. We want to understand whether self-identity value significantly influences the purchase behaviour of luxury brands.

Ho: Self-identity value does not significantly influence the purchase behaviour of luxury brands 
H1: Self-identity value significantly influences the purchase behaviour of luxury brands The study by Wiedmann et al (2009) has shown that self-identity value is an important dimension of luxury value. We want to test whether this is applicable in our study.

(viii) Hedonic value: Consumers may be attracted to luxury brands because of characteristics such as comfort, beauty and pleasure. This shows that consumers are looking for a positive emotional experience. We want to understand whether hedonic value significantly influences the purchase behaviour of luxury brands.

Ho: Hedonic value does not significantly influence the purchase behaviour of luxury brands

H1: Hedonic value significantly influences the purchase behaviour of luxury brands

The study by Wiedmann et al (2009) has shown that hedonic value is an important dimension of luxury value. We want to test whether this is applicable in our study.

(ix) Materialistic value: Materialism can be divided into three parts: centrality, happiness and success. Centrality indicates that luxury possessions play a central role in the lives of materialists. Happiness is the belief that owning the right possessions leads to well-being and materialists believe that the things people own can judge success. We want to understand whether materialistic value significantly influences the purchase behaviour of luxury brands.

Ho: Materialistic value does not significantly influence the purchase behaviour of luxury brands

H1: Materialistic value significantly influences the purchase behaviour of luxury brands

The study by Wiedmann et al (2009) has shown that materialistic value is an important dimension of luxury value. We want to test whether this is applicable in our study as this model is emerging market like India .Middle class population of India is going to overshadow the population of many western countries.

\section{Objectives}

(i) To understand the different luxury value perceptions among consumers: Here we have identified four important luxury dimensions namely financial value, functional value, social value and individual value based on our literature review. We want to study how these luxury dimensions influence the purchase behavior of luxury brands for luxury consumers in Mumbai.

(ii) To try to segment the consumers based on the luxury value dimensions: Here we will use cluster analysis to segment the customers based on the luxury value dimensions. The characteristics of luxury customers will vary from one cluster to the other. Accordingly, luxury brand companies can cater to the requirements of customers in each cluster by using different strategies.

Study becomes important, as India is a developing economy with middle class population exceeding the population of many western countries. China and India will become the powerhouses of middle class consumerism over the next two decades.

\section{Research Methodology}

To measure the underlying dimensions of consumers' luxury value perceptions, in this study we have used already existing tested measures (Dubois and Laurent, 1994; O'Cass and McEwen, 2004; Richins and Dawson, 1992; Tsai, 2005; Tian et al., 2001; Wiedmann et al., 2009) and generated various items based on the literature review. The important components of luxury value dimensions are considered for constructing questionnaire items. 329 respondents completed a questionnaire consisting of 57 items.

\section{Sample characteristics and data collection}

Data are collected using a structured questionnaire. All respondents completed the instrument in Mumbai, India. The sample seems to well represent India's emerging young, educated, affluent urban middle class. Table 1 shows that males outnumbered females 2:1. The sample was fairly young with $48 \%$ of respondents younger than the age of 25 and $49 \%$ between the ages of 25 and 40 . One third identified as students while $47 \%$ identified as professionals. The remaining respondents $20 \%$ identified as retired or homemakers. Seventy percent were single. All were at least college educated with $60 \%$ indicating that they had completed post-graduate work. Average earnings were between 50000 and 100000 Rupees (USD 800 - \$1600 per month). This is given in table-1. The Kaiser-Meyer-Olkin measure of sampling adequacy (KMO), with a value of 0.851 , which is greater than 0.7 shows that the sample size was sufficiently large to conduct factor analyses, described in the results section of this study.

Place Table-1 here

\section{Data Analysis}

Structural equation modelling (SEM) is employed in the present research to test the proposed model. The maximum likelihood method maximises the probability that the observed covariances are drawn from a population that has its variance and the process implied by the model (Golob, 2003) generates covariance. In the 
present study, maximum likelihood is used in the SEM analysis. Goodness-of-fit tests are used to determine if a proposed model is consistent with the pattern of variances and covariance's in the data. SEM is used in this research to test conceptual models and hypotheses

According to the literature, SEM is particularly appropriate for the study of multiple dependence relationships such as those investigated in the present research. SEM was used in this research to determine if the estimated population covariance matrix of the proposed model was consistent with the observed covariance matrix. The software package utilised for SEM in this research is the AMOS 7.0 statistical package due to its user friendliness. AMOS can link directly to SPSS and provides a graphical user interface that allows the researcher to configure path diagrams, calculate model fit and estimate parameters. Other methods used for data analysis are factors and cluster analysis.

\section{Factor analysis:}

\section{Results}

Factor analysis is first carried out on the various reasons or factors responsible for buying luxury brands.---- There were eight statements showing the reasons for buying luxury brands and after factor analysis we were able to reduce them to three major factors i.e. prestige value(.765), individual value(.746) and quality value(..662)

Similarly, we carried out factor analysis on 'Personal attitude towards luxury consumption' where there are 11 statements. We are able to reduce them to 3 factors namely personal attitude related to prestige (.834), personal attitude related to uniqueness (.724) and personal attitude related to individual/snob value(.794). Model fit summary for personal attitude for luxury brand using Amos software for using structural equation model reveals:

Model Fit Summary for personal attitude:

CMIN

\begin{tabular}{|l|rrrrr|}
\hline Model & NPAR & CMIN & DF & P & CMIN/DF \\
\hline Default model & 48 & 327.680 & 142 & .000 & 2.308 \\
Saturated model & 190 & .000 & 0 & & \\
Independence model & 19 & 1970.688 & 171 & .000 & 11.524 \\
\hline
\end{tabular}

RMR, GFI

\begin{tabular}{|l|rrrr|}
\hline \multicolumn{7}{c|}{ RMR, GFI } \\
\hline Model & RMR & GFI & AGFI & PGFI \\
\hline Default model & .075 & .907 & .876 & .678 \\
Saturated model & .000 & 1.000 & & \\
Independence model & .232 & .478 & .420 & .430 \\
\hline
\end{tabular}

Hence, all the conditions for assessment of goodness of fit are satisfied since Chisquare $/ \mathrm{df}<5$, GFI $>$ 0.9 and AGFI $>0.8$

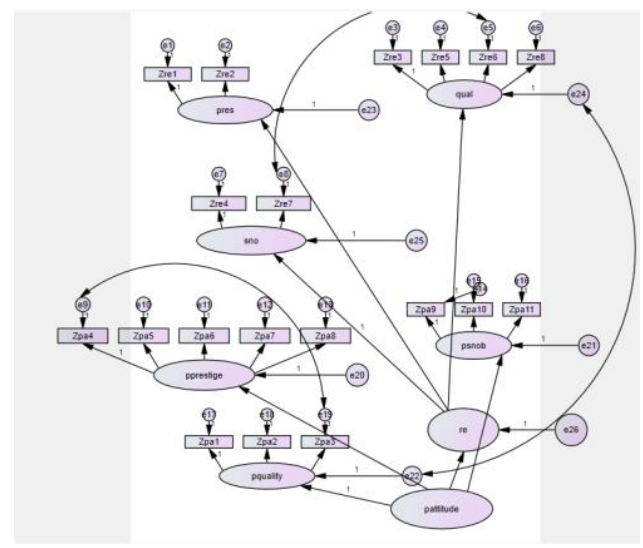

Explanation of the diagram: The personal attitude factors comprise of personal attitude for quality, personal attitude for prestige and personal attitude for snob. There is a linkage between personal attitude and reason. Through structural equation modelling, we conclude that the standardised regression coefficient for personal attitude influencing reason is significant and the significance value i.e. $\mathrm{p}$ value is very small i.e. less than 0.05 The next factor analysis is on 'Functional value' where there are five statements. We are able to reduce them to two factors namely quality with usability value (.834) and uniqueness value(.833). 
Model fit summary for Functional for luxury brand using Amos software for using structural equation model reveals:

Model fit for Functional value: Baseline Comparisons

\begin{tabular}{|l|rrrrr|}
\hline Model & $\begin{array}{r}\text { NFI } \\
\text { Delta1 }\end{array}$ & $\begin{array}{r}\text { RFI } \\
\text { rho1 }\end{array}$ & $\begin{array}{r}\text { IFI } \\
\text { Delta2 }\end{array}$ & $\begin{array}{r}\text { TLI } \\
\text { rho2 }\end{array}$ & CFI \\
\hline Default model & .859 & .811 & .921 & .891 & .919 \\
Saturated model & 1.000 & & 1.000 & & 1.000 \\
Independence model & .000 & .000 & .000 & .000 & .000 \\
\hline
\end{tabular}

\begin{tabular}{|l|rrrrr|}
\multicolumn{1}{l|}{ CMIN } \\
\hline Model & NPAR & CMIN & DF & P & CMIN/DF \\
\hline Default model & 33 & 121.268 & 58 & .000 & 2.091 \\
Saturated model & 91 & .000 & 0 & & \\
Independence model & 13 & 861.196 & 78 & .000 & 11.041 \\
\hline
\end{tabular}

Hence all the conditions for assessment of goodness of fit are satisfied since Chisquare $/ \mathrm{df}<5$, GFI > 0.9 and AGFI $>0.8$

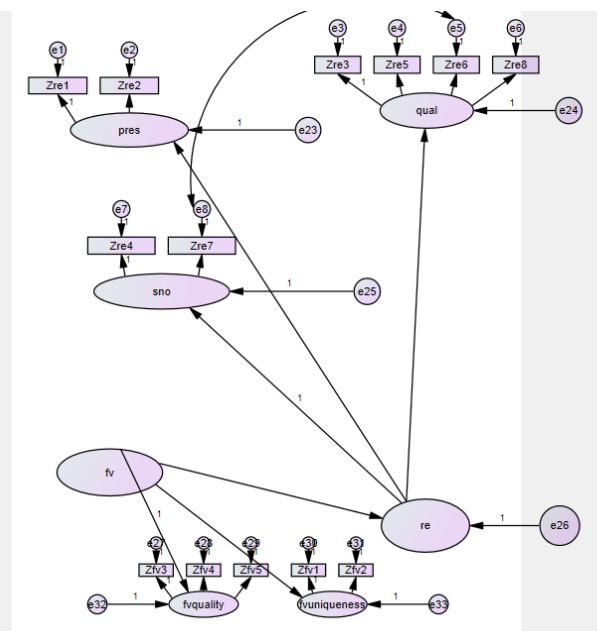

Explanation of the diagram: The functional value factors comprise of quality and for uniqueness. When we use structural equation modelling, we find that the standardised regression coefficient for functional value influencing reason is significant and the significance value i.e. $p$ value is very small i.e. less than 0.05

Factor analysis on 'Individual value' where there are 8 statements reduced them to 2 factors namely hedonic with materialistic value (.774) and self-identity value(.734) in our next analysis

Model fit summary for Individual value for luxury brand using Amos software for using structural equation model reveals:

Model fit for Individual values: CMIN

\begin{tabular}{|l|rrrrr|}
\hline Model & NPAR & CMIN & DF & P & CMIN/DF \\
\hline Default model & 39 & 189.012 & 97 & .000 & 1.949 \\
Saturated model & 136 & .000 & 0 & & \\
Independence model & 16 & 1128.943 & 120 & .000 & 9.408 \\
\hline
\end{tabular}

\section{Baseline Comparisons}

\begin{tabular}{|l|rrrrr|}
\hline Model & $\begin{array}{r}\text { NFI } \\
\text { Delta1 }\end{array}$ & $\begin{array}{r}\text { RFI } \\
\text { rho1 }\end{array}$ & $\begin{array}{r}\text { IFI } \\
\text { Delta2 }\end{array}$ & $\begin{array}{r}\text { TLI } \\
\text { rho2 }\end{array}$ & CFI \\
\hline Default model & .833 & .793 & .911 & .887 & .909 \\
Saturated model & 1.000 & & 1.000 & & 1.000 \\
Independence model & .000 & .000 & .000 & .000 & .000 \\
\hline
\end{tabular}


Hence all the conditions for assessment of goodness of fit are satisfied since Chisquare /df $<5$, GFI >

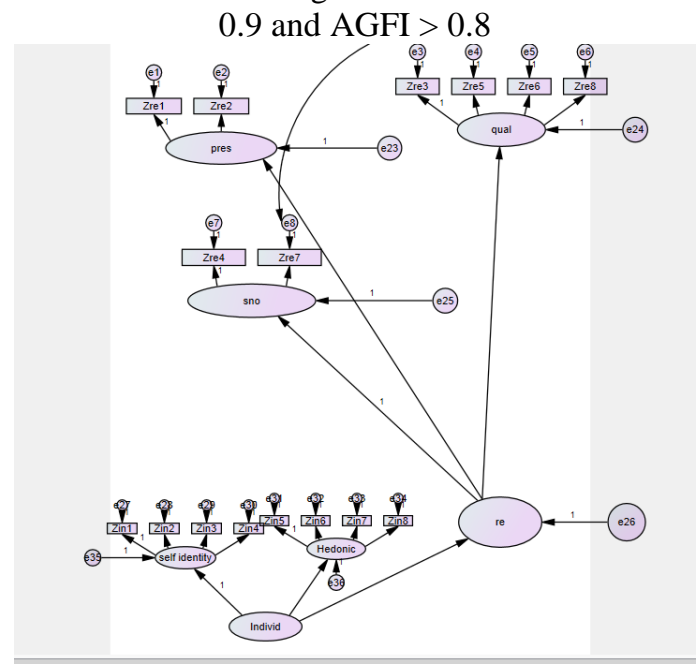

Explanation of the diagram: The individual value comprises of individual value for self-identity and individual value for hedonic value. Structural equation modelling reveals that the standardised regression coefficient for individual value influencing reason is significant and the significance value i.e. $p$ value is very small i.e. less than 0.05 .

Factor analysis of 'social value', where there are 7 statements reduced to only one factor namely, prestige with snob value(.801)

Model fit summary for social value for luxury brand using Amos software for using structural equation model reveals:

Model fit for social values:

CMIN

\begin{tabular}{|l|rrrrr|}
\hline Model & NPAR & CMIN & DF & P & CMIN/DF \\
\hline Default model & 35 & 194.992 & 85 & .000 & 2.294 \\
Saturated model & 120 & .000 & 0 & & \\
Independence model & 15 & 1479.656 & 105 & .000 & 14.092 \\
\hline
\end{tabular}

RMR, GFI

\begin{tabular}{|l|rrrr|}
\hline Model & RMR & GFI & AGFI & PGFI \\
\hline Default model & .070 & .930 & .902 & .659 \\
Saturated model & .000 & 1.000 & & \\
Independence model & .247 & .502 & .431 & .440 \\
\hline
\end{tabular}

Hence all the conditions for assessment of goodness of fit are satisfied since Chisquare /df $<5$, GFI $>0.9$ and AGFI $>0.8$

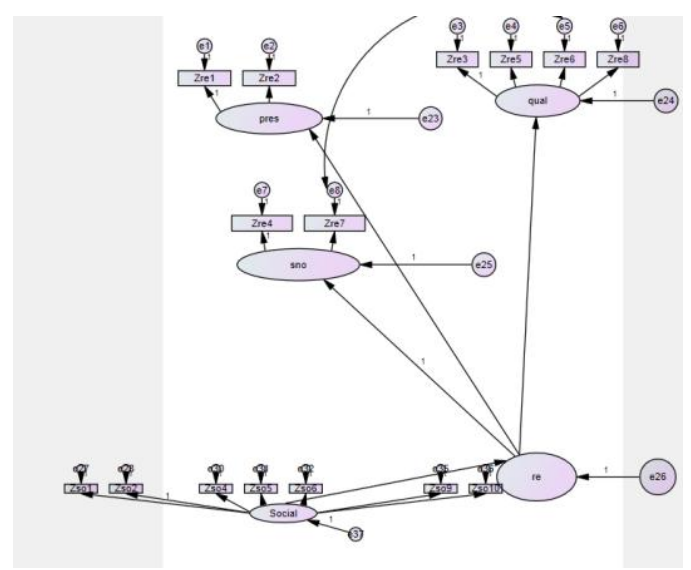


Explanation of the diagram: The social value comprises of prestige value and snob value.. When we use structural equation modelling, we find that the standardised regression coefficient for social value influencing reason is significant and the significance value i.e. $p$ value is very small i.e. less than 0.05

Reliability of the scales is measured by computing the Cronbach alpha. For all the factors used in this research, reliability values had a range between 0.55 and 0.85 .This is given in table- 2

\section{Place Table-2 here}

The second part is to analyse the hypotheses and have used different statistical test. The summary of the test is given below in table 3 .

Place table-3 here

\section{Linkage of factors with Wiedmann's model}

As per the model developed by Wiedmann et at (2009), there were four main luxury value dimensions i.e. (i) Financial value (ii) Functional value (iii) Individual value (iv) Social value. These were further categorised as :

1. Financial value

2. Functional value : (a) Quality value (b) Uniqueness value (c) Usability value

3. Individual value: (a) Hedonic value (b) Self-identity value (c) Materialistic value

4. Social value : (a) Prestige value (b) Conspicuous value

We have studied the above model and replaced conspicuous value by Snob value. Then we tried to validate the model with the data collected from respondents as mentioned in our methodology. We observed the following important results

(i) From factor analysis of reasons to buy luxury products, we identified 3 major factors i.e. individual value, social value and quality value.

(ii) From factor analysis of personal attitude statements, we got 3 factors namely financial value, prestige value and snob value.

(iii) From factor analysis of functional value statements, we got 2 factors namely quality\& usability value and uniqueness value.

(iv) From factor analysis of individual value statements, we got 2 factors namely self-identity value and hedonic\& materialistic value.

(v) From factor analysis of social value statements, we got only one factor which comprised of prestige value and snob value.

(vi) We used structural equation modelling to validate our model with the data. We assessed the goodness of fit of each of the constructs using criteria like chisquare/df, GFI, AGFI and they all satisfied the minimum criteria to show a good fit.

(vii) We found the reliability of each of the scales using Cronbach alpha. Then we found the composite reliability of each of the four main constructs using Bagozzi and Yi's (1998) composite reliability (CR) index and they were all greater than the evaluation criteria of 0.6 indicating high composite reliability. This means that the statements taken in each construct were able to explain the construct in a satisfactory manner.

(viii) We found the convergent validity of each construct using AVE (Average variance extracted) using Fornell and Larcker's (1981) average variance extracted (AVE) index and they were all greater than the evaluation criteria of 0.5 , indicating that at least $50 \%$ of the variance in a measure is due to the hypothesized underlying trait (e.g., Fornell \& Larcker, 1981).

(ix) We also checked the discriminant validity and found that the constructs had good discriminant validity since AVE for each construct is higher than the square of the correlation parameter estimated with other constructs (Fornell and Larcker, 1981).

\section{Validation of the model in the context of Indian luxury consumers:}

We had used the model developed by Wiedmann et al (2009) and replaced conspicuous value by snob value. We found that all the luxury value dimensions considered by us had a significant influence on purchase behaviour of luxury brands. This means that luxury buyers in India consider the following most important attributes while purchasing luxury brands

(i) Financial value: They feel that a luxury brand has to be premium priced otherwise it will be within the reach of even the masses.

(ii) Quality value: The luxury brand has to have the best quality and long life and durability as compared to a non-luxury brand 
(iii) Uniqueness value: The luxury product should be unique and provide exclusivity to the consumer.

(iv) Usability value: The luxury product should be able to satisfy all the needs of the consumer.

(v) Self-identity value: The luxury consumer should be able to identify himself/herself with the characteristics of the brand.

(vi) Hedonic value: The luxury product should give a feeling of happiness and pleasure to the consumer in terms of beauty, aesthetics and good looks.

(vii) Materialistic value: The ownership of the luxury brands shows the person's success and accomplishments and he/she likes a life fulfilled with luxury.

(vi) Prestige value: The luxury consumer tries to conform to high status groups by owning these brands.

(vii) Snob value: The luxury consumer tries to differentiate himself/herself from the masses by owning these brands and would not like to buy a brand, which is possessed by many, and stops using them when it becomes popular. They also want to show-off their possessions.

From the results, we concluded that there are four important dimensions of luxury value namely financial value, functional value individual value and social value. This means that when a luxury customer wants to buy a luxury brand, he/she would look at these aspects to make a decision.

Hence luxury brand companies should see that their products should be premium priced, should have high quality and usability value, should give a feeling of pleasure to the customer, should be unique, rare and exclusive, should give a feeling of prestige and self-identity to the customer and should be a symbol of success and achievement.

The third stage involved part cluster analysis to classify respondents based on the nine factors representing the independent variables corresponding to the nine initial hypotheses. These factors included: quality value, hedonic value, uniqueness value, usability value, self identity value, prestige value, snob value, financial value and materialistic value. According to hierarchical method, the results suggested the presence of three clusters. These three clusters are used as an input into non-hierarchical k-means clustering. The results point out that the perceived luxury value variables appeared to make considerable contribution in characterizing clusters.

Luxury value segments based on k-means clustering results are shown as follows:

Cluster 1: This group consists of people with high uniqueness value and high snob value. They buy special products, do not buy products, which are widely accepted, and buy luxury brands for satisfying personal needs. They believe that luxury products cannot be sold in supermarkets and cannot be mass-produced. They are not bothered about the aesthetic appeal or brand image or feel.

Cluster 2 : This group consists of people who are high on almost all dimensions of luxury value i.e. prestige value, self-identity value, quality value, uniqueness value and hedonic value. They feel that luxury brands should have a strong brand image, good quality, aesthetic appeal and great history. They feel that the brand should be consistent with their characteristics, should be able to express their individuality and should be unique and exclusive. It should be expensive, should be able to satisfy personal needs, and have feel good properties. They feel that these brands will give them self-actualisation, and help them belong to the group that possesses such products. These people want to be appreciated because of their accomplishments and to be recognised and admired by high society.

Cluster 3: This group consists of people who are high on quality value, hedonic value and uniqueness value. They want brands with good quality, strong brand image, aesthetic appeal, and great history. They feel that luxury brands should satisfy their personal needs, should be consistent with their characteristics and cannot be mass produced. They do not buy luxury products that others admire or to be recognised by high society. They do not purchase to show off that they can afford them and don't stop using products just because they are widely accepted. They also do not buy luxury brands, when they are in a bad mood, to alleviate their burden. This is shown in Table 4

Place table-4

\section{Discussion}

The main purpose of this study is to understand the different luxury value perceptions among consumers. To reach our goal, factor analysis was first performed on the provided questionnaire and its output was condensed to nine major factors. The nine factors obtained were Prestige value, Self-identity value, quality value, Uniqueness value, Hedonic value, Materialistic value, Snob value, Usability value and Financial value. Then the consumer market for luxury goods was segmented and the differences between clusters with respect to the nine luxury value dimensions were observed. Findings revealed three behaviourally distinct segments. The 
first group consisted of people with high uniqueness value and high snob value. The second group consisted of people who are high on almost all dimensions of luxury value i.e. prestige value, self-identity value, quality value, uniqueness value and hedonic value. The third group consisted of people who are high on quality value, hedonic value and uniqueness value. Marketers can apply suitable strategies based on financial, functional, social and individual value dimensions in each group.

We can assign weight ages from 1 to 3 to the different dimensions for each segment depending on the value sought after by the customers.

\section{Segment 1}

Let us assign the following weight ages to the different values.

\begin{tabular}{|l|l|l|}
\hline $\begin{array}{l}\text { Dimensions of } \\
\text { Luxury value }\end{array}$ & Weight age & Justification \\
\hline $\begin{array}{l}\text { Uniqueness } \\
\text { UN }\end{array}$ & 3 & $\begin{array}{l}\text { These customers want to look different and unique from others and hence purchase luxury } \\
\text { brands. Hence highest weightage is given. }\end{array}$ \\
\hline Snob S & 3 & $\begin{array}{l}\text { These customers want to own something that is very expensive or exclusive , for the status } \\
\text { one gets by owning it.Hence highest weightage is given. }\end{array}$ \\
\hline $\begin{array}{l}\text { Prestige P } \\
\text { Self-identity } \\
\text { value I }\end{array}$ & 2 & $\begin{array}{l}\text { The quest for prestige value is high but less as compared to uniqueness value and snob value. } \\
\text { Hence lesser weightage is given. }\end{array}$ \\
\hline $\begin{array}{l}\text { Quality Q } \\
\text { The quest for self-identity value is high but less as compared to uniqueness value and snob } \\
\text { value. Hence lesser weightage is given. }\end{array}$ & $\begin{array}{l}\text { The quest for quality value is high but less as compared to uniqueness value and snob value. } \\
\text { Hence lesser weightage is given. }\end{array}$ \\
\hline $\begin{array}{l}\text { Hedonic value } \\
\text { H }\end{array}$ & 2 & $\begin{array}{l}\text { The quest for hedonic value is high but less as compared to uniqueness value and snob value. } \\
\text { Hence lesser weightage is given. }\end{array}$ \\
\hline $\begin{array}{l}\text { Materialistic } \\
\text { value M }\end{array}$ & 2 & $\begin{array}{l}\text { The quest for materialistic value is high but less as compared to uniqueness value and snob } \\
\text { value. Hence lesser weightage is given. }\end{array}$ \\
\hline $\begin{array}{l}\text { Usability } \\
\text { value U }\end{array}$ & 1 & $\begin{array}{l}\text { The quest for usability value is much lesser as compared to uniqueness value and snob value. } \\
\text { Hence least weightage is given. }\end{array}$ \\
\hline $\begin{array}{l}\text { Financial F } \\
\text { The quest for financial value is high but less as compared to uniqueness value and snob } \\
\text { value. Hence lesser weightage is given. }\end{array}$ \\
\hline
\end{tabular}

Hence if we take luxury value as $\mathrm{L}$, then we can write a mathematical model as

$\mathrm{L}=(\mathrm{k} 1 * 3 \mathrm{UN})(\mathrm{k} 2 * 3 \mathrm{~S})(\mathrm{k} 3 * 2 \mathrm{P})(\mathrm{k} 4 * 2 \mathrm{I})(\mathrm{k} 5 * 2 \mathrm{Q})(\mathrm{k} 6 * 2 \mathrm{H})(\mathrm{k} 7 * 2 \mathrm{M})(\mathrm{k} 8 * 1 \mathrm{U})(\mathrm{k} 9 * 2 \mathrm{~F})$

Explanation: Here k1,k2,k3,k4,k5,k6,k7,k8 and k9 are constants . The constant has been multiplied with the weightage given to the different dimensions.

\section{Segment 2}

Let us assign the following weightages to the different values.

\begin{tabular}{|c|c|c|}
\hline $\begin{array}{l}\text { Dimensions of } \\
\text { Luxury value }\end{array}$ & Weightage & Justification \\
\hline $\begin{array}{l}\text { Uniqueness } \\
\text { UN }\end{array}$ & 3 & $\begin{array}{l}\text { These customers want to look different and unique from others and hence purchase luxury } \\
\text { brands. Hence highest weightage is given. }\end{array}$ \\
\hline Snob S & 2 & $\begin{array}{l}\text { The quest for snob value is high but less as compared to the other values. Hence lesser } \\
\text { weightage is given. }\end{array}$ \\
\hline Prestige $\mathrm{P}$ & 3 & The quest for prestige value is very high. Hence highest weightage is given. \\
\hline $\begin{array}{l}\text { Self-identity } \\
\text { value I }\end{array}$ & 3 & The quest for self-identity value is very high. Hence highest weightage is given. \\
\hline Quality Q & 3 & The quest for quality value is very high. Hence highest weightage is given. \\
\hline $\begin{array}{l}\text { Hedonic value } \\
\mathrm{H}\end{array}$ & 3 & The quest for hedonic value is very high. Hence highest weightage is given. \\
\hline $\begin{array}{l}\text { Materialistic } \\
\text { value } \mathrm{M}\end{array}$ & 3 & The quest for materialistic value is also very high. Hence highest weightage is given. \\
\hline $\begin{array}{l}\text { Usability } \\
\text { value U }\end{array}$ & 2 & $\begin{array}{l}\text { Thequest for usability value is high but less as compared to other values. Hence lesser } \\
\text { weightage is given. }\end{array}$ \\
\hline Financial $\mathrm{F}$ & 2 & $\begin{array}{l}\text { The quest for financial value is high but less as compared to other values. Hence lesser } \\
\text { weightage is given. }\end{array}$ \\
\hline
\end{tabular}

Hence if we take luxury value as $\mathrm{L}$, then we can write a mathematical model as

$\mathrm{L}=(\mathrm{k} 10 * 3 \mathrm{UN})(\mathrm{k} 11 * 2 \mathrm{~S})(\mathrm{k} 12 * 3 \mathrm{P})(\mathrm{k} 13 * 3 \mathrm{I})(\mathrm{k} 14 * 3 \mathrm{Q})(\mathrm{k} 15 * 3 \mathrm{H})(\mathrm{k} 16 * 3 \mathrm{M})(\mathrm{k} 17 * 2 \mathrm{U})(\mathrm{k} 18 * 2 \mathrm{~F})$

Explanation: Here k10,k11,k12,k13,k14,k15,k16,k17 and k18 are constants . The constant has been multiplied with the weightage given to the different dimensions. 


\section{Segment 3}

Let us assign the following weightages to the different values.

\begin{tabular}{|c|c|c|}
\hline $\begin{array}{l}\text { Dimensions of } \\
\text { Luxury value }\end{array}$ & Weightage & Justification \\
\hline $\begin{array}{l}\text { Uniqueness } \\
\text { UN }\end{array}$ & 3 & $\begin{array}{l}\text { These customers want to look different and unique from others and hence purchase luxury } \\
\text { brands. Hence highest weightage is given. }\end{array}$ \\
\hline Snob S & 1 & $\begin{array}{l}\text { The quest for snob value is quite less as compared to other values. Hence least weightage is } \\
\text { given. }\end{array}$ \\
\hline Prestige $\mathrm{P}$ & 2 & $\begin{array}{l}\text { The quest for prestige value is high but less as compared to other values. Hence lesser weightage } \\
\text { is given. }\end{array}$ \\
\hline $\begin{array}{l}\text { Self-identity } \\
\text { value I }\end{array}$ & 1 & $\begin{array}{l}\text { The quest for self-identity value is quite less as compared to other values. Hence least weightage } \\
\text { is given. }\end{array}$ \\
\hline Quality Q & 3 & The demand for quality value is very high. Hence highest weightage is given. \\
\hline $\begin{array}{l}\text { Hedonic value } \\
\mathrm{H}\end{array}$ & 3 & The demand for hedonic value is very high. Hence highest weightage is given. \\
\hline $\begin{array}{l}\text { Materialistic } \\
\text { value } \mathrm{M}\end{array}$ & 2 & $\begin{array}{l}\text { The demand for materialistic value is high but less as compared to other values. Hence lesser } \\
\text { weightage is given. }\end{array}$ \\
\hline $\begin{array}{l}\text { Usability } \\
\text { value U }\end{array}$ & 2 & $\begin{array}{l}\text { The demand for usability is high but less as compared to other values. Hence least weightage is } \\
\text { given. }\end{array}$ \\
\hline Financial $\mathrm{F}$ & 2 & $\begin{array}{l}\text { The demand for financial value is high but less as compared to other values. Hence lesser } \\
\text { weightage is given. }\end{array}$ \\
\hline
\end{tabular}

Hence if we take luxury value as $\mathrm{L}$, then we can write a mathematical model as

$\mathrm{L}=(\mathrm{k} 19 * 3 \mathrm{UN})(\mathrm{k} 20 * 1 \mathrm{~S})(\mathrm{k} 21 * 2 \mathrm{P})(\mathrm{k} 22 * 1 \mathrm{I})(\mathrm{k} 23 * 3 \mathrm{Q})(\mathrm{k} 24 * 3 \mathrm{H})(\mathrm{k} 25 * 2 \mathrm{M})(\mathrm{k} 26 * 2 \mathrm{U})(\mathrm{k} 27 * 2 \mathrm{~F})$

Explanation: Here k19,k20,k21,k22,k23,k24,k25,k26 and k27 are constants . The constant has been multiplied with the weightage given to the different dimensions.

\section{Conclusions}

From hypothesis testing, we have concluded that there are nine important dimensions of luxury value namely functional value, financial value, usability value, hedonic value, uniqueness value, snob value, prestige value, self-identity value and materialistic value. This means that when a luxury customer wants to buy a luxury brand, he/she would look at these aspects to make a decision. Hence luxury brand companies should see that their products should be premium priced, should have high functional and usability value, should give a feeling of pleasure to the customer, should be unique, rare and exclusive, should give a feeling of prestige and selfidentity to the customer and should be a symbol of success and achievement. From cluster analysis, we have divided the luxury customers into three segments or clusters, each showing different characteristics and preference towards the different dimensions. Brand managers can cater to each segment with different strategies in order to satisfy their requirements and aspirations.

Benefits of the study: Knowledge of all relevant aspects of consumer perceptions of luxury can be useful for managerial practice. From the market segmentation view, this study suggests that the luxury market is no longer homogenous. According to perceived values in luxury brands, different sets of luxury products and different types of advertising strategies are applied with focus on the more important values for each group. Even if consumers buy the same luxury goods, their perceptions about luxury values can differ, so the luxury market is heterogeneous and the role of product characteristics plays an important role. Thus, it is the marketer's duty to consider individual differences in evaluating luxury values and provide them products which satisfy their requirements.

Managerial implications: Keeping the hypothesis in mind, we have seen that there are nine luxury dimensions namely financial value, quality value, usability value, hedonic value, uniqueness value, uniqueness value, snob value, prestige value, self-identity value and materialistic value. We can say that the value for money (VFM) for a luxury customer depends on these 9 dimensions. Hence we can construct a VFM matrix. We can consider top 10 brands in different sectors like apparel, pens, watches etc. and ask the respondents to give a rating from 1 to 5 on all these 9 dimensions. Then, assuming that each dimension is given a weightage as 10, we can find the weighted average score for each brand. If a brand, gets a low score on a particular dimension, then this becomes a weak spot for valuation of the model and the brand managers should do research and appropriate strategies should be used to improve the brand equity. We have validated this VFM model at the student level by conducting a pilot study of 50 students and now this can be done at the consumer level.

Limitations: First, the sample size taken is small which may not be a very good representation of the population. Secondly, only the overall perceptions about luxury value have been tested. We can apply similar analysis for a specified luxury product or service. Thirdly, the influence of demographic characteristics on purchase behaviour of luxury brands has not been studied. We can find out how the various luxury dimensions influence of various occupations, age groups, gender, income groups and educational levels. This becomes the scope for further research. 


\section{References}

[1]. Aaker, D., 1991.' Managing Brand Equity: Capitalizing on the Value of a Brand Name', Free Press, New York.

[2]. Bell, S.S., Holbrook, M.B and Solomon, M.R. (1991). Combining Aesthetic and Social Value to Explain Preferences for Product Styles with Incorporation of Personality and Ensemble Effects. To Have Possessions: A Handbook on Ownership and Property Journal of Social Behaviour and Personality. 6 (6), pp. 243-274

[3]. Bourne, F. S. (1957). Group Influence in Marketing and Public Relations. in Some Applications of Behavioural Research, eds. R. Likert and S.P. Hayed, Basil, Switzerland: UNESCO.

[4]. Braun, Ottmar L. and Robert Wicklund. (1989). Psychological Antecedents of Conspicuous Consumption. Journal of Economic Psychology,10, (June), pp.161-87.

[5]. Chadha, R., \& Husband, P. (2006). 'The cult of the luxury brand: Inside Asia's love affair with luxury', London: Nicholas Brealey International

[6]. Chaudhuri, H. R., \& Majumdar, S. (2006). Of diamonds and desires: understanding conspicuous consumption from a contemporary marketing perspective. Academy of Marketing Science Review, 6 (11), 256-267.

[7]. Chelsey Latter, Ian Phau et al, 'The role of consumers' need for uniqueness and status consumption in Haute Couture luxury brands'.

[8]. Danziger, P.M., 2005. ' Let them Eat Cake: Marketing Luxury to the Masses-as Well as the Classes' Dearborn Trade Publishing, Chicago.

[9]. Dhar, R., \& Wertenbroch, K. (2000). Consumer choice between hedonic and utilitarian goods. Journal of Marketing Research, 37 (2), 60-71.

[10]. Dubois, B. and G. Laurent, 1994.' Attitudes toward the Concept of Luxury: An Exploratory Analysis' In: Leongand, S. and J. Cote (Eds.), Asia Pacific Advances in Consumer Research. Association for Consumer Research, Provo, UT, pp: $273-278$.

[11]. Dubois, B. and S. Czellar, 2002.' Prestige Brands or Luxury Brands? An Exploratory Inquiry on Consumer Perceptions. HEC Geneva, Retrieved from: www.hec.unige.ch/recherchespublications/, (Accessed on: April 28, 2009).Res. J. Appl. Sci. Eng. Technol., 5(5): 1681-1688, 20131688

[12]. Dubois, B., S. Czellar and G. Laurent, 2001.'Consumer Rapport to Luxury: Analyzing Complex and Ambivalent Attitudes.' Retrieved from: http:/ www.hec, fr/hec/fr/ professeurs-recherché, (Accessed on: March 12, 2010).

[13]. Dubois, B. \& Paternaut, C. (1995), "Observations: Understanding The World of International Luxury Brands: The Dream Formula", Journal of Advertising Research, Vol. 35 No.4, pp. 69-76

[14]. Graeff, T.R., 1996. 'Using promotional messages to manage the effects of brand and self-image on brand evaluations', Journal of Consumer Marketing, 31(4): 4-18.

[15]. Han,Y.J , J.C.Nunes and X. Dreze, 2011, 'Signaling status with luxury goods: The role of brand prominence'

[16]. Hong Jae W and Zinkhan George M (1995), "Self Concept and Advertising Effectiveness: The Influence of Congruency, Conspicuousness, and Response Mode", Psychology and Marketing, Vol. 12, No. 1, pp. 53-77.

[17]. Horiuchi Yoshihide (1984), "A Systems Anomaly: Consumer Decision Making Process for Luxury Goods", Unpublished Doctoral Dissertation, University of Pennylvania.

[18]. Kapferer, J.N., 1997.' Managing luxury brands', Journal of Brand Management., 4(4): 251-260.

[19]. Khor Eng Tatt, 2010, 'Factors influencing consumer buying behaviour of luxury branded goods'.

[20]. Kohli, C. and Thakor, M. (1997). Branding Consumer Goods: Insights Form Theory and Practice. Journal of Consumer Marketing, 14 (3), pp.206-219.

[21]. Leibenstein, H. (1950), "Bandwagon, Snob, and Veblen Effects in the Theory of Consumers' Demand", The Quarterly Journal of Economics, Vol. 64, No. 2. (May), pp. 183-207.

[22]. Mason, R. S., 1981, Conspicuous Consumption: A Study of Exceptional Behaviour, Gower, UK

[23]. O'Cass, A. and H. Frost, 2002. 'Status brands: Examining the effects of non-product brand

[24]. associations on status and conspicuous consumption', Journal of Product \& Brand Management., 11: 7-88.

[25]. O'Cass, A. and H. McEwen, 2004,' Exploring consumer status and conspicuous consumption', Journal of Consumer Behaviour., 4(1): 25-39.

[26]. Paurav Shukla. (2010). Status (luxury) consumption in cross-national context: Managerial implications. Luxury marketing. http://www.pauravshukla.com/status-luxury-consumption-in-cross-national-contextmanagerial-implications

[27]. Quelch, J.A., 1987. 'Marketing the premium product', Journal of Business Horizons, 30: 38-45.

[28]. Richins, M., 1994. 'Special possessions and the expression of the material values'. Journal of Consumer Research, 21: 522-533.

[29]. Richins, M. and S. Dawson, 1992. 'A consumer values orientation for materialism and its measurement: Scale development and validation', Journal of Consumer Research, 19: 303-316.

[30]. Rozenberg, M., 1979 ' Conceiving the Self', Basic Books, New York.

[31]. Sun, M.W., 2011 'Consumption of luxury fashion brands: The motives of generation Y consumers in China', MS Thesis, Auckland University of Technology.

[32]. Teck-Yong Eng, 2010, 'Psychological and cultural insights into consumption of luxury western brands in India', Journal of Customer Behaviour,.9(1):55-75

[33]. Teimourpour Bahar et al, (2013) Segmenting consumers based on luxury value perceptions', Research Journal of Applied Sciences, Engineering and Technology 5(5): 1681-1688,

[34]. Tian, K.T., W.O. Beaden and G.L. Hunter, 2001 'Consumers' need for uniqueness: Scale

[35]. development and validation', Journal of Consumer Research, 28: 50-66.

[36]. Tsai, S., 2005. 'Impact of personal orientation on luxury-brand purchase value', International Journal of Marketing Research,47(4): 429-454.

[37]. Veblen, T., 1899 'The Theory of the Leisure Class', New American Library, New York.

[38]. Vigneron, F. and L.W. Johnson, 2004 'Measuring perceptions of brand luxury', Journal of Brand Management', 11: 484-506.

[39]. Virginie de Barnier, Irina Rodina, 'Which luxury perceptions affect most consumer purchase behaviour ? A cross cultural exploratory study in France, UK and Russia'.

[40]. Wiedmann, K.P., N. Hennigs and A. Siebels, 2009 ' Value-based segmentation of luxury consumption behaviour', Journal of Psychology \& Marketing., 26: 625-651

[41]. Wong, N.Y. \& Ahuvia, A.C. (1998), Personal taste and family face: luxury consumption in Confucian and Western societies, Psychology and Marketing, Vol. 15 No.5, pp. 423-41 
Web references

1. en.wikipedia.org/wiki/Luxury goods

2. www.pauravshukla.com/segmenting-luxury-brand-consumers

3. www.luxurydaily.com/tag/emerging-markets/

4. www.luxurydaily.com

Annexure

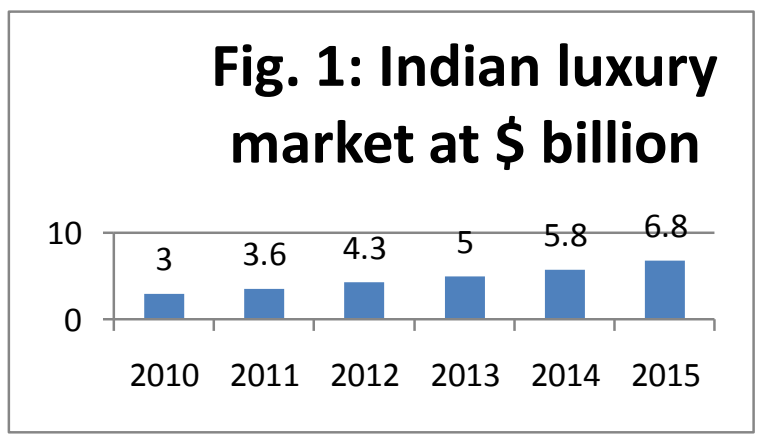

Source: India luxury trends (2011-12) report by Technopak

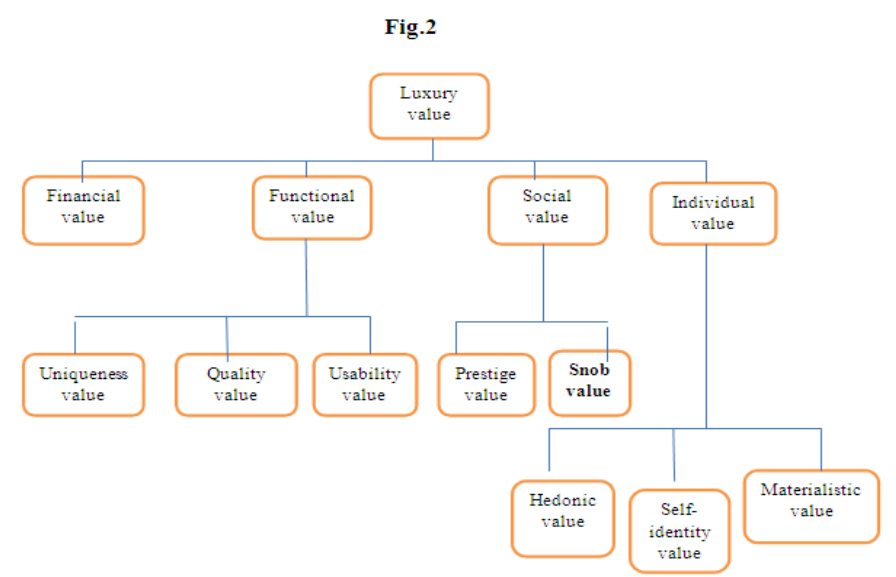

Adapted from Wiedmann's model, Academy of Marketing Science Review, 2007 with new additional variable as snob value

Table 1:Demographic profile analysis

\begin{tabular}{lll}
\hline Gender & Male 67\% & Female 33\% \\
\hline Age & $<2548 \%$ & $25-4049 \%$ \\
Occupation & Student 33\% & Professional 47\% \\
Marital Status & Single 70\% & Married/Widowed 30\% \\
Education & College 97\% & Postgraduate 60\% \\
Monthly Income & 50K-100 RS 70\% & \\
\hline
\end{tabular}

Table-2: Luxury factors and Cronbach alpha

\begin{tabular}{|l|l|}
\hline Type of luxury value & Cronbach alpha \\
\hline Financial Value & 0.618 \\
\hline Quality value & 0.653 \\
\hline Usability value & 0.551 \\
\hline Uniqueness value & 0.794 \\
\hline Self-identity value & 0.58 \\
\hline Hedonic value & 0.62 \\
\hline Materialistic value & 0.56 \\
\hline Prestige value & 0.73 \\
\hline Snob value & 0.761 \\
\hline
\end{tabular}


Table-3: Testing of hypothesis

\begin{tabular}{|c|c|c|c|c|c|c|}
\hline Dimension & $\begin{array}{l}\text { Composite } \\
\text { reliability }\end{array}$ & $\begin{array}{l}\text { AVE (Convergent } \\
\text { validity) }\end{array}$ & Hypothesis & $\beta$ value & $P$ value & $\begin{array}{l}\text { Status of } \\
\text { hypothesi } \\
\text { s }\end{array}$ \\
\hline \multirow[t]{3}{*}{$\begin{array}{l}\text { Personal } \\
\text { attitude }\end{array}$} & \multirow[t]{3}{*}{0.767} & \multirow[t]{3}{*}{0.53} & $\begin{array}{l}\text { Financial value } \\
\text { significantly } \\
\text { influences purchase } \\
\text { behaviour of luxury } \\
\text { brands }\end{array}$ & 0.536 & $<0.05$ & Accepted \\
\hline & & & $\begin{array}{l}\text { Prestige value } \\
\text { significantly } \\
\text { influences purchase } \\
\text { behaviour of luxury } \\
\text { brands }\end{array}$ & 0.854 & $<0.05$ & Accepted \\
\hline & & & $\begin{array}{l}\text { Snob value } \\
\text { significantly } \\
\text { influences purchase } \\
\text { behaviour of luxury } \\
\text { brands }\end{array}$ & 0.763 & & Accepted \\
\hline \multirow[t]{2}{*}{$\begin{array}{l}\text { Functional } \\
\text { value }\end{array}$} & 0.66 & 0.51 & $\begin{array}{l}\text { Quality value and } \\
\text { usability value } \\
\text { significantly } \\
\text { influence purchase } \\
\text { behaviour of luxury } \\
\text { brands }\end{array}$ & 0.724 & $<0.05$ & Accepted \\
\hline & & & $\begin{array}{l}\text { Uniqueness value } \\
\text { significantly } \\
\text { influences purchase } \\
\text { behaviour of luxury } \\
\text { brands }\end{array}$ & 0.456 & $<0.05$ & Accepted \\
\hline \multirow[t]{2}{*}{$\begin{array}{l}\text { Individual } \\
\text { value }\end{array}$} & 0.65 & 0.52 & $\begin{array}{l}\text { Hedonic value and } \\
\text { materialistic value } \\
\text { significantly } \\
\text { influence purchase } \\
\text { behaviour of luxury } \\
\text { brands }\end{array}$ & 0.499 & $<0.05$ & Accepted \\
\hline & & & $\begin{array}{l}\text { Self-identity value } \\
\text { significantly } \\
\text { influences purchase } \\
\text { behaviour of luxury } \\
\text { brands }\end{array}$ & 0.779 & $<0.05$ & Accepted \\
\hline Social value & 0.857 & 0.51 & $\begin{array}{l}\text { Prestige value and } \\
\text { snob value } \\
\text { significantly } \\
\text { influence purchase } \\
\text { behaviour of luxury } \\
\text { brands }\end{array}$ & 0.216 & $<0.05$ & Accepted \\
\hline
\end{tabular}

Table 4:Final Cluster Centres

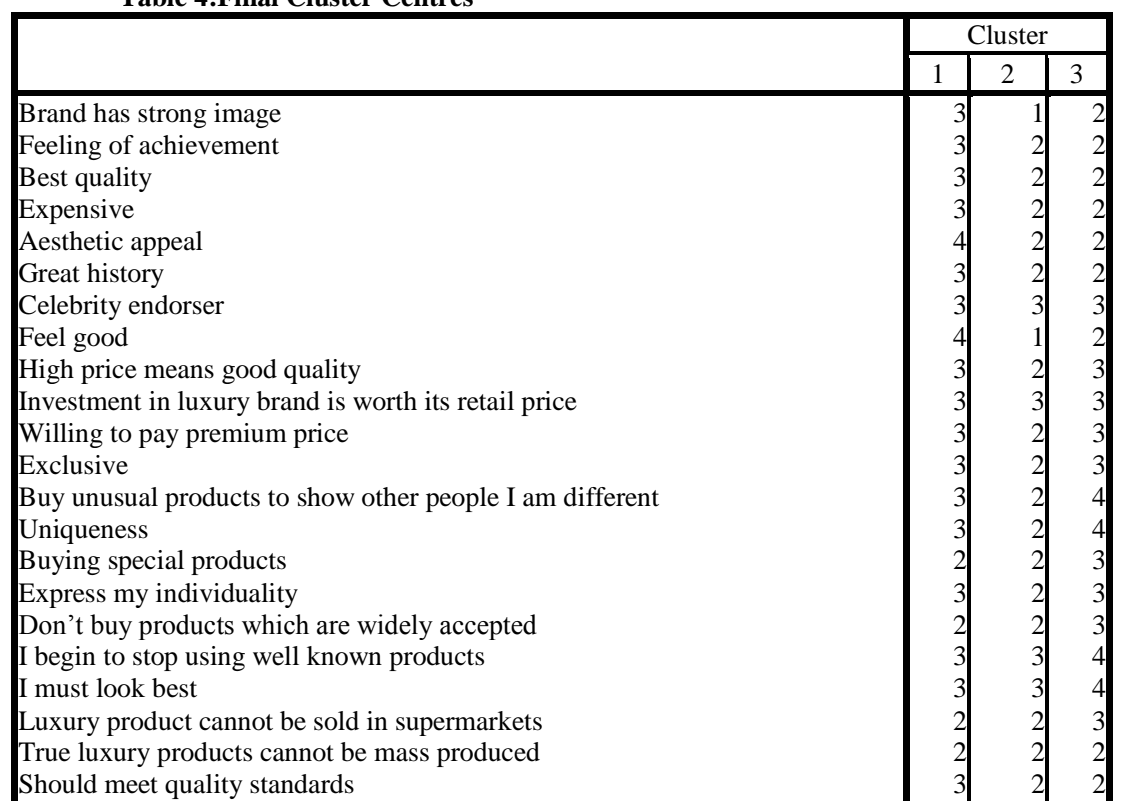


Evaluate attributes and performance of luxury brand myself

Buy luxury brands for satisfying personal needs

I buy luxury brand consistent with my characteristics

My life would be better if I owned certain things

My choice depends on whether they reflect how I see myself

I regard luxury brands as gifts I buy for treating myself

When in bad mood I buy luxury brands to alleviate burden

Provides deeper meaning in my life

Self actualisation is an important motivator

I like to have my life fulfilled with luxury

What brands make good impressions on others

I keep up with style changes by watching what others buy

If I buy something expensive I worry about what others think of me

What others think of people who use certain products

I buy products that others admire

I feel I belong to the group that purchases products

I want to be appreciated because of accomplishments

I like to present to people who are close to me

I purchase luxury brands to show off that I can afford them

I will be recognised and admired by high society

\begin{tabular}{l|l|l|}
3 & 2 & 2 \\
2 & 2 & 2 \\
3 & 2 & 2 \\
3 & 2 & 3 \\
3 & 2 & 2 \\
3 & 2 & 3 \\
3 & 3 & 4 \\
3 & 3 & 4 \\
3 & 2 & 3 \\
3 & 2 & 3 \\
3 & 2 & 3 \\
2 & 2 \\
3 & 2 & 3 \\
3 & 3 & 4 \\
3 & 3 & 4 \\
3 & 3 & 4 \\
3 & 2 & 4 \\
3 & 2 & 3 \\
3 & 2 & 3 \\
3 & 3 & 4 \\
3 & 2 & 4 \\
\hline
\end{tabular}

From cluster analysis, we have divided the luxury customers into three segments or clusters, each showing different characteristics and preference towards the different dimensions. 